\title{
Potensi Quercetin-3-0-Glucoside (Q3g) dan Quercetin-4-0-Glucoside (Q4g) dari Daun Mimba (Azadirachta indica a.juss) terhadap Ambilan Glukosa
}

\author{
Enny Rohmawaty, Vycke Yunivita \\ Departemen Farmakologi dan Terapi Fakultas Kedokteran Universitas Padjadjaran
}

\begin{abstract}
Abstrak
Daun mimba (Azadirachta indica A.Juss) yang berasal dari BPT Situbondo memiliki zat aktif quercetin-3-Oglucoside (Q3G) dan quercetin-4-O-glucoside (Q4G) yang diketahui mempunyai kemampuan menghambat ambilan glukosa melalui membran usus halus. Penelitian ini bertujuan mengetahui potensi isolat dan dosis optimal Q3G dan Q4G dari daun mimba terhadap ambilan glukosa melalui membran usus halus tikus putih (Rattus rattus novergicus). Zat aktif Q3G dan Q4G dari daun mimba diisolasi secara kualitatif dengan metode Kromatografi Lapis Tipis (KLT). Penelitian ini dilakukan di beberapa tempat, antara lain: Laboratorium Kimia Organik FMIPA Unpad, Laboratorium Biokimia FK Unpad, serta Laboratorium Farmakologi dan Terapi FK Unpad. Penelitian dilakukan pada bulan Juni-Desember 2011. Penelitian laboratorium eksperimental dengan rancangan acak lengkap dilakukan terhadap 30 ekor tikus putih yang dibagi dalam 5 kelompok. Kelompok kontrol diberi larutan glukosa 3,0 x 10-3 M, dan 4 kelompok perlakuan diberi larutan glukosa berturut-turut Q3G $1 \mathrm{mg} / \mathrm{kgBB}, \mathrm{Q} 3 \mathrm{G} 2 \mathrm{mg} / \mathrm{kgBB}$, Q4G $1 \mathrm{mg} / \mathrm{kgBB}$, dan Q4G $2 \mathrm{mg} / \mathrm{kgBB}$ menggunakan alat perfusi in situ. Kadar ambilan glukosa diamati setiap 15 menit selama 1 jam. Data dianalisis menggunakan one-way ANOVA dan tes Duncan dengan taraf kepercayaan 95\% $(\alpha=0,05)$. Hasil penelitian menunjukkan sebanyak 53,1 mg isolat Q3G dan 14,4 mg Q4G diperoleh dari daun mimba BPT Situbondo sebanyak $1 \mathrm{~kg}$. Isolat Q3G $1 \mathrm{mg} / \mathrm{kgBB}, \mathrm{Q} 4 \mathrm{G} 1 \mathrm{mg} / \mathrm{kgBB}$, dan Q4G $2 \mathrm{mg} / \mathrm{kgBB}$ berbeda secara bermakna dalam menghambat ambilan glukosa melalui membran usus halus tikus dibanding dengan kontrol pada menit ke-45 ( $<<0,05)$. Simpulan, isolat Q3G dan Q4G dari daun mimba dapat menghambat ambilan glukosa melalui membran usus halus tikus putih. [MKB. 2016;48(4):222-7]
\end{abstract}

Kata kunci: Ambilan glukosa, daun mimba, Q3G, Q4G

\section{Potential Influence of Quercetin-3-0-Glucoside (Q3g) and Quercetin-4-0- Glucoside (Q4g) from Mimba Leaves (Azadirachta indica a.juss) on Glucose Uptake}

\begin{abstract}
Mimba leaves (Azadirachta indica A.Juss), which was obtained from Brigade Proteksi Tanaman (BPT) Situbundo in this study, contain active compounds of quercetin-3-0-glucoside (Q3G) and quercetin-4'-0-glucoside (Q4G). These compounds were isolated using the Thin Layer Chromatography (TLC). From previous studies, Q3G and Q4G are known to inhibit the glucose uptake from intestinal membrane. This study was conducted to understand the potential influence of Q3G and Q4G isolated from mimba leaves in inhibiting glucose uptake in rat's intestinal membrane (Rattus rattus norvegicus). This experimental study employed 30 male rats that met the inclusion criteria that were divided into 5 groups $(n=6)$. Group I was the control group and only received glucose solution 3,0 x 10-3 M. Group II, III, IV, and V received glucose solution with Q3G $1 \mathrm{mg} / \mathrm{kgBW}, \mathrm{Q} 3 \mathrm{G} 2 \mathrm{mg} / \mathrm{kgBW}, \mathrm{Q} 4 \mathrm{G} 1 \mathrm{mg} /$ $\mathrm{kgBW}$, and Q4G $12 \mathrm{mg} / \mathrm{kgBW}$, respectively. The inhibitory potentials of Q3G and Q4G on glucose uptake was measured every 15 minutes for one hour using in situ perfusion equipment. Data were analyzed using One-way ANOVA and Duncan test with a significance level 95\% ( $\alpha=0.05)$. From $1 \mathrm{~kg}$ fresh mimba leaves, $60.1 \mathrm{mg}$ Q3G and $14.4 \mathrm{mg}$ Q4G were isolated. This study showed that Q3G $1 \mathrm{mg} / \mathrm{kgBW}, \mathrm{Q} 4 \mathrm{G} 1 \mathrm{mg} / \mathrm{kgBW}$, and Q4G $2 \mathrm{mg} / \mathrm{kgBW}$ significantly inhibited glucose uptake from rat intestinal membrane compared to negative control at 45th minute $(\mathrm{p}<0.05)$. Therefore, Q3G and Q4G isolated from mimba leaves have significantly inhibit glucose uptake from rat's intestinal membrane (Rattus rattus norvegicus). [MKB. 2016;48(4):222-7]
\end{abstract}

Key words: Glucose uptake, mimba leaves, Q3G, Q4G

Korespondensi: Dr. Enny Rohmawaty, dr., M.Kes. Departemen Farmakologi dan Terapi Fakultas Kedokteran Universitas Padjadjaran, Jalan Prof. Eijkman No. 38 Bandung, mobile 08157133135, e-mail enny.farmakologi@gmail.com 


\section{Pendahuluan}

Penderita diabetes melitus (DM) di dunia maupun di Indonesia kejadiannya meningkat dengan pesat. International Diabetes Federation (IDF) menyatakan bahwa pada tahun 2013 terdapat 382 juta penderita diabetes melitus di dunia dan diperkirakan akan meningkat menjadi 592 juta orang pada tahun 2035. Survei Kesehatan Rumah Tangga (SKRT) 2001 menyatakan bahwa prevalensi diabetes melitus pada penduduk usia 25-64 tahun di Jawa dan Bali sebesar 7,5\%. Riset Kesehatan Dasar (Riskesdas) 2013 menyatakan proporsi penderita diabetes pada penduduk usia $\geq 15$ tahun di Indonesia sebesar 6,9\% atau sekitar 12 juta orang. ${ }^{1}$

Diabetes melitus adalah kumpulan gejala yang timbul pada seseorang disebabkan oleh peningkatan glukosa darah akibat kekurangan insulin, baik absolut maupun relatif. Defisiensi insulin dapat terjadi akibat kerusakan sel-sel $\beta$ pankreas, desensitisasi atau penurunan reseptor glukosa pada kelenjar pankreas dan kerusakan reseptor insulin (down regulation) di jaringan perifer. $^{2}$

Morbiditas dan mortalitas akibat diabetes melitus ini diakibatkan oleh pola hidup yang tidak sehat. Karbohidrat dalam makanan akan melalui proses pencernaan dan penyerapan dalam usus halus. Pola makan tinggi karbohidrat meningkatkan kadar glukosa darah. Glukosa diabsorbsi dari lumen usus masuk ke dalam enterosit pertama kali mempergunakan protein transporter SGLT-1 yang berada pada brush border membran usus halus dan ditranspor ke pembuluh darah dari enterosit menggunakan protein transporter GLUT-2 melalui membran basolateral. Enterosit itu bertanggung jawab terhadap kadar glukosa dalam lumen usus halus dan mengatur transporter glukosa SGLT-1. Kadar glukosa yang tinggi dalam darah mengganggu toleransi terhadap glukosa darah yang dapat menginduksi DM tipe 2.2,3

Secara empiris banyak tanaman yang telah digunakan untuk mengobati DM, di antaranya daun mimba (Azadirachta indica A. Juss.). Daun mimba mengandung quercetin yang diduga mempunyai efek dapat menurunkan kadar gula darah., ${ }^{2,3}$ Penelitian yang dilakukan pada kelinci menunjukkan bahwa ekstrak daun dan akar mimba mampu mengontrol kadar glukosa darah. ${ }^{5}$ Quercetin secara in vitro mempunyai efek menghambat ambilan glukosa yang diperantarai transporter GLUT 2 dan secara in vivo terbukti menghambat absorpsi glukosa pada tikus yang obes dan menderita diabetes. ${ }^{6}$ Penelitian yang lain menyimpulkan bahwa Q3G dan Q4G menghambat SGLT-1 menangkap $\mathrm{Na}^{+2}$ dari lumen usus sehingga transpor natrium-glukosa terhambat. 6,7

Penelitian ini bertujuan mengetahui potensi serta dosis optimal Q3G dan Q4G daun mimba terhadap ambilan glukosa pada membran usus halus tikus.

\section{Metode}

Penelitian ini dilakukan di beberapa tempat, antara lain Laboratorium Kimia Organik FMIPA Unpad, Laboratorium Biokimia FK Unpad, serta Laboratorium Farmakologi dan Terapi FK Unpad. Penelitian dilakukan pada bulan Juni-Desember 2011.

Daun mimba yang digunakan penelitian ini berasal dari BPT Situbondo, kemudian dilakukan determinasi tanaman di Laboratorium Biologi ITB. Proses isolasi diawali dengan pengeringan daun menggunakan lemari pengering bersuhu $40^{\circ} \mathrm{C}$ hingga menjadi simplisia yang kemudian dihaluskan menjadi serbuk. Serbuk daun mimba kering sebanyak $100 \mathrm{mg}$ dibungkus dengan kertas saring, kemudian dilakukan soxhletasi menggunakan pelarut metanol $800 \mathrm{~mL}$. Hasil soxhletasi kemudian dipekatkan dengan rotary evaporator sehingga terbentuk ekstrak metanol daun mimba. Ekstrak metanol yang terbentuk kemudian dipartisi dengan n-heksana dan air sebanyak 3 kali sampai terbentuk fraksi heksana dan fraksi air. Fraksi air kemudian dipartisi sebanyak 3 kali dengan etil asetat sehingga terbentuk fraksi air dan fraksi etil asetat. Setelah itu, dilakukan pengujian secara kualitatif dengan kromatografi lapis tipis (KLT) menggunakan pelat ODS dengan 3 kali elusi terhadap semua fraksi hasil partisi, sampai tampak pemisahan senyawa Q3G dan Q4G. Kromatografi kolom dilakukan lebih lanjut terhadap fraksi etil asetat menggunakan silika G 60 (n-heksana-aseton; gradien $10 \%$ ). Untuk mendapatkan target isolat Q3G dan Q4G yang masih tertahan di silika maka dilakukan pencucian menggunakan $3 \times 60 \mathrm{~mL}$ metanol. Hasil pencucian mengalami KLT untuk kedua kalinya, dengan ODS menggunakan pelarut metanol:air=7:3. Tahapan yang selanjutnya ialah dilakukan penentuan senyawa isolat dan juga membandingkannya dengan standar Q3G serta Q4G.

Subjek penelitian ini adalah 30 ekor tikus putih (Rattus novergicus albinus) yang memenuhi kriteria inklusi: (1) berjenis kelamin jantan; (2) umur 3-4 bulan dengan bobot badan tikus 150- 
250 gram; dan (3) sehat. Kriteria eksklusi antara lain (1) penurunan bobot badan selama adaptasi lebih dari 10\% dari bobot badan awal; dan (2) terlihat sakit selama masa adaptasi.

Tikus dibagi menjadi lima kelompok, terdiri atas kelompok kontrol yang diberi larutan glukosa $3,0 \times 10^{-3} \mathrm{M}$, dan empat kelompok uji yang berturut-turut diberi larutan glukosa dan Q3G 1 $\mathrm{mg} / \mathrm{kg} \mathrm{BB}, \mathrm{Q} 3 \mathrm{G} 2 \mathrm{mg} / \mathrm{kg} \mathrm{BB}, \mathrm{Q} 4 \mathrm{G} 1 \mathrm{mg} / \mathrm{kg} \mathrm{BB}$, dan Q4G $2 \mathrm{mg} / \mathrm{kg}$ BB. Tikus dipuasakan 16-18 jam sebelum penelitian dimulai dan hanya diberi air minum secukupnya. Tikus kemudian dianestesi menggunakan uretan $15 \% \quad(1,15$ $\mathrm{mL} / 100 \mathrm{~g}$ BB tikus) dan tubuh tikus difiksasi pada papan. Setelah itu, dilakukan pembedahan pada abdomen tikus. Jejunum tikus dilubangi pada jarak awal $10 \mathrm{~cm}$ dari bagian pilorus gaster, dan ujungnya pada jarak $25 \mathrm{~cm}$ sesudahnya, dan dipasangkan kanul. Jejunum dicuci dengan larutan $\mathrm{NaCl}$ 0,9\% yang dilanjutkan dengan peniupan sebanyak 3 kali untuk membersihkan kotoran. Dua buah kanul kemudian dipasangkan pada jejunum untuk dihubungkan ke alat perfusi. Glukosa dimasukkan ke dalam bejana alat perfusi, lalu dialirkan dengan alat pompa sehingga terjadi aliran bolak-balik melalui usus dengan kecepatan 16 kali per menit. Larutan diambil pada menit ke-15, 30, 45, dan 60 untuk dilakukan analisis kadar glukosa sisa yang diserap.

Kadar glukosa sisa tersebut kemudian diukur dengan metode spektrofotometri. Pertamatama larutan yang akan dianalisis mengalami deproteinisasi mempergunakan TCA 8\% 500 uL, lalu disentrifugasi dan $100 \mathrm{uL}$ supernatan kemudian dicampur dengan $1 \mathrm{~mL}$ reagen dan diinkubasi dalam penangas $37^{\circ} \mathrm{C}$ selama 10 menit. Absorbansi glukosa dengan spektrofotometer $505 \mathrm{~nm}$ menggunakan blangko larutan standar reagen dari ST reagensia dengan kadar 200 $\mathrm{mg} / \mathrm{L}$.

Data hasil pengamatan dianalisis secara statistik dengan one way ANOVA. Hipotesis yang diuji berupa pengujian efek isolat Q3G dan Q4G terhadap ambilan glukosa melalui membran jejunum tikus. Keadaan ini ditunjukkan dengan terdapat perbedaan antara kadar glukosa yang diserap tanpa isolat Q3G/Q4G dan kadar glukosa yang diserap dengan pemberian isolat Q3G/ Q4G. Uji statistik one way ANOVA dilanjutkan dengan uji Duncan dengan taraf kepercayaan 95\% $(\mathrm{p}<0,05)$. Analisis dilakukan menggunakan program komputer statistik SPSS.

Pelaksanaan penelitian ini dilakukan setelah mendapatkan persetujuan dari Komite Etik Penelitian Kesehatan Fakultas Kedokteran Unpad, dengan surat Keterangan Persetujuan Etik No: 87/FKUP-RSHS/KEPK/Kep./EC/2011. Implikasi etik pada hewan coba, yaitu berupa pengelolaan hewan coba, menggunakan prinsip 3R (replacement, refinement, dan reduction).

\section{Hasil}

Isolat Q3G sebanyak 53,1 mg dan Q4G sebanyak $14,4 \mathrm{mg}$ diperoleh dari daun mimba BPT Situbondo sebanyak $1 \mathrm{~kg}$ melalui metode KLT. Isolat Q3G dan Q4G tersebut kemudian diujicobakan pada subjek penelitian. Tabel. 1 menunjukkan kadar glukosa rata-rata dalam lumen usus halus tikus yang tidak terabsorpsi. Setelah glukosa dan bahan uji dimasukkan ke dalam bejana alat perfusi, lalu dialirkan dengan alat pompa sehingga terjadi aliran bolak-balik melalui usus dengan kecepatan 16 kali per menit. Larutan kemudian diambil pada menit ke15, 30, 45, dan 60 untuk dilakukan analisis kadar glukosa sisa yang diserap. Kadar glukosa sisa yang tinggi menunjukkan bahwa bahan uji yang

Tabel 1 Kadar Glukosa pada Kelompok Kontrol dan Uji (Pemberian Q3G 1 mg, Q3G 2 mg, Q4G $1 \mathrm{mg}$, dan Q4G $2 \mathrm{mg}$ )

\begin{tabular}{lccccc}
\hline & \multicolumn{5}{c}{ Kadar Glukosa (mg/dL) } \\
\cline { 2 - 6 } Jenis Perlakuan & Baseline & $\mathbf{1 5}$ & $\mathbf{3 0}$ & $\mathbf{4 5}$ & $\mathbf{6 0}$ \\
\hline Kontrol & 239,938 & 229,629 & 220,472 & 215,275 & 215,560 \\
Q3G 1 mg & 245,536 & 232,540 & 246,230 & 252,431 & 246,776 \\
Q3G 2 mg & 243,637 & 239,293 & 240,391 & 239,867 & 224,816 \\
Q4G 1 mg & 284,444 & 262,460 & 268,988 & 293,849 & 285,397 \\
Q4G 2 mg & 303,564 & 302,147 & 296,950 & 279,979 & 289,703 \\
\hline
\end{tabular}


Tabel 2 Kadar Ambilan Glukosa pada Kelompok Kontrol dan Uji (Pemberian Q3G 1 mg, Q3G 2 mg, Q4G 1 mg, dan Q4G 2 mg

\begin{tabular}{lcccc}
\hline \multirow{2}{*}{ Jenis Perlakuan } & \multicolumn{4}{c}{ Ambilan Glukosa (mg/dL) } \\
\cline { 2 - 5 } & $\mathbf{1 5}$ & $\mathbf{3 0}$ & $\mathbf{4 5}$ & $\mathbf{6 0}$ \\
\hline Kontrol & 10,309 & 19,467 & 24,663 & 28,686 \\
Q3G 1 mg & 17,510 & $4 ., 167$ & 4,564 & 5,010 \\
Q3G 2 mg & 10,838 & 15,428 & 5.753 & 22,127 \\
Q4G 1 mg & 25,318 & 25,536 & 8,472 & 5,913 \\
Q4G 2 mg & 4,988 & 7,805 & 2.381 & 15,608 \\
\hline
\end{tabular}

ditambahkan memiliki potensi penghambatan ambilan glukosa yang baik (glukosa kurang diabsorpsi oleh usus halus). Hal ini ditunjukkan oleh bahan uji Q4G 2 mg dengan kadar glukosa sebesar 302,147 mg/dL pada menit ke-15. Hal ini terlihat perbedaan yang signifikan dengan kelompok kontrol dengan kadar glukosanya $229,629 \mathrm{mg} / \mathrm{dL}$. Kadar glukosa sisa yang rendah memperlihatkan bahwa bahan uji yang ditambahkan memiliki potensi penghambatan ambilan glukosa yang buruk (glukosa banyak terserap oleh usus halus). Hal ini ditunjukkan oleh bahan uji Q3G 2 mg dengan kadar glukosa sebesar 224,816 mg/dL.

Tabel 2 menunjukkan kadar ambilan glukosa rata-rata dalam lumen usus halus tikus. Kadar ambilan glukosa diketahui dari selisih kadar glukosa dalam lumen usus halus menit ke-15, 30, 45, dan 60 dengan kadar glukosa baseline. Kadar ambilan glukosa terkecil menunjukkan potensi hambatan ambilan glukosa dari bahan uji yang paling baik. Hal ini ditunjukkan oleh Q4G 2 mg (2,381 $\mathrm{mg} / \mathrm{dL})$ pada menit ke- 45 .

Perbandingan ambilan glukosa melalui membran jejunum tikus dapat dilihat pada Gambar. Dari Gambar dilihat bahwa terdapat perbedaan kadar ambilan glukosa kelompok kontrol dengan kelompok pemberian isolat Q3G $1 \mathrm{mg} / \mathrm{kg} \mathrm{BB}, \mathrm{Q} 3 \mathrm{G} 2 \mathrm{mg} / \mathrm{kgBB}, \mathrm{Q} 4 \mathrm{G} 1 \mathrm{mg} / \mathrm{kgBB}$, dan Q4G 2 mg/kgBB.

Data hasil penelitian kemudian dianalisis secara statistik dengan one way ANOVA dan apabila terdapat perbedaan yang signifikan maka analisis dilanjutkan dengan Uji Lanjutan Duncan.

Tabel 3 menunjukkan hasil analisis statistik mempergunakan one way ANOVA. Dari tabel tersebut terlihat bahwa terdapat perbedaan kadar ambilan glukosa yang signifikan pada menit ke-45 perfusi sehingga dilakukan uji lanjutan Duncan.

Berdasarkan atas tabel Homogenous Subsets didapatkan efek penghambatan kadar ambilan glukosa melalui membran usus halus tikus berbeda bermakna dengan kelompok kontrol pada menit ke- 45 perfusi, pada pemberian isolat Q3G $1 \mathrm{mg} / \mathrm{kgBB}$ tikus, Q4G $1 \mathrm{mg} / \mathrm{kgBB}$, dan Q4G $2 \mathrm{mg} / \mathrm{kgBB}$.

Hasil penelitian ini memperlihatkan bahwa terdapat perbedaan efek ambilan glukosa antara kelompok kontrol dan kelompok perlakuan pemberian isolat Q3G $1 \mathrm{mg} / \mathrm{kgBB}, \mathrm{Q} 3 \mathrm{G} 2 \mathrm{mg} /$ $\mathrm{kgBB}, \mathrm{Q} 4 \mathrm{G} 1 \mathrm{mg} / \mathrm{kgBB}$, dan Q4G $2 \mathrm{mg} / \mathrm{kgBB}$ pada menit ke-45, dengan ambilan glukosa ratarata $3,769 \mathrm{mg} / \mathrm{dL}$. Tidak terdapat perbedaan efek ambilan glukosa antara kelompok kontrol dan kelompok perlakuan pemberian isolat Q3G 1 $\mathrm{mg} / \mathrm{kgBB}$, Q3G $2 \mathrm{mg} / \mathrm{kgBB}, \mathrm{Q} 4 \mathrm{G} 1 \mathrm{mg} / \mathrm{kgBB}$, dan

Tabel 3 Hasil Analisis Statistik (One Way ANOVA)

\begin{tabular}{ccc}
\hline Kadar Ambilan Glukosa Menit ke- & F & Sig \\
\hline 15 & 0,346 & 0,844 \\
30 & 0,564 & 0,691 \\
45 & 3,563 & 0,020 \\
60 & 2,215 & 0,096 \\
\hline
\end{tabular}


Enny R.: Potensi Quercetin-3-O-Glucoside (Q3g) dan Quercetin-4-O-Glucoside (Q4g) dari Daun Mimba terhadap Ambilan Glukosa

Tabel 4 Hasil uji Post Hoc Duncan

\begin{tabular}{lcc}
\hline \multicolumn{1}{c}{ Jenis Perlakukan } & Subset for alpha=0,05 & 1 \\
\hline Q4G 2 mg/KgBB & $\mathbf{2}$ & \\
Q4G 1 mg/kgBB & $-9,748$ & \\
Q3G 1 mg/kgBB & $-8,294$ & 3,769 \\
Q3G 2mg/kgBB & $-6,895$ & 24,663 \\
Kontrol & 3,769 & \\
Sig. & & \\
\hline
\end{tabular}

Q4G 2 mg/kgBB pada menit ke-15, 30, dan 60 .

\section{Pembahasan}

Proses pembuatan isolat dari daun mimba menunjukkan bahwa dari $1 \mathrm{~kg}$ daun mimba segar dari BPT Situbondo diperoleh 600 gram daun mimba kering. Dari 100 gram daun mimba kering diperoleh 18 gram ekstrak metanol. Ekstrak metanol daun mimba kemudian difraksinasi dan diperoleh fraksi etil asetat sebanyak 2 gram yang kemudian difraksinasi dan dimurnikan sehingga diperoleh isolat Q4G sebanyak 14,4 mg dan Q3G sebanyak 60,1 mg. ${ }^{9-12}$ Dengan demikian, diketahui bahwa dari $1 \mathrm{~kg}$ daun mimba segar BPT Situbondo mengandung isolat Q3G sebesar 60,1 mg dan Q4G sebanyak 14,4 mg.

Hasil penelitian menunjukkan bahwa isolat

Q3G 1 dan $2 \mathrm{mg} / \mathrm{kg}$ BB dan isolat Q4G 1 dan $2 \mathrm{~m} /$ kgBB yang diisolasi dari daun mimba memiliki efek dalam menghambat ambilan glukosa pada usus halus (jejunum) tikus dibanding dengan kontrol. Keadaan ini sesuai dengan penelitianpenelitian sebelumnya.

Pada penelitian yang lain, diketahui bahwa zat aktif dalam daun mimba yang berperan dalam menurunkan kadar gula darah ialah quercetin. ${ }^{4,6,10}$ Rainer dkk. ${ }^{7}$ meneliti efek penghambatan dari quercetin terhadap absorpsi glukosa pada membran brush border jejunum babi. Didapatkan simpulan bahwa Q3G dan Q4G menghambat SGLT-1 menangkap $\mathrm{Na}^{+2}$ dari lumen usus sehingga transpor natrium-glukosa melewati membran brush border jejunum terhambat. Apabila dalam diet monosakarida terdapat quercetin maka akan terjadi penghambatan transpor glukosa, terutama yang diperantarai oleh transporter SGLT1. Pada penelitian ini didapatkan bahwa

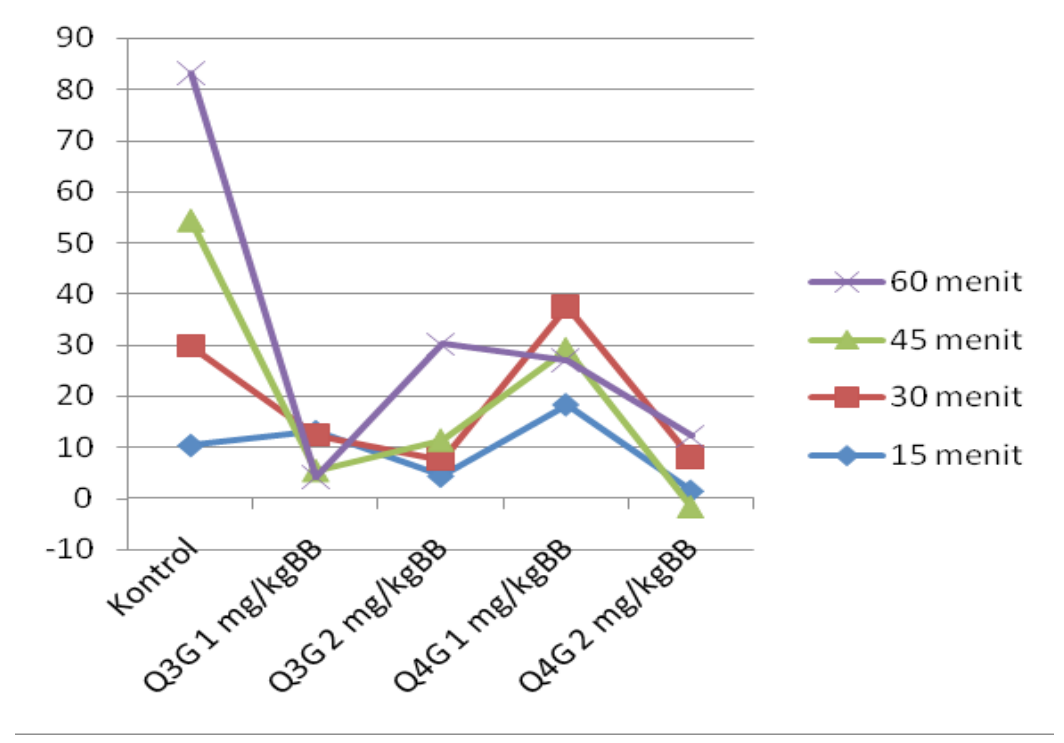

Gambar Perbandingan Kadar Ambilan Glukosa antara Kelompok Kontrol dan Perlakuan 
baik isolat Q3G maupun isolat Q4G memiliki efek dalam penghambatan absorpsi glukosa dan sejalan dengan penelitian yang dilakukan oleh Rainer dkk. tersebut.

Berdasarkan uji statistik menggunakan One way ANOVA, diketahui bahwa penghambatan ambilan glukosa terjadi secara signifikan pada menit ke-45. Kemungkinan hal ini terjadi oleh karena pada menit ke-15 dan 30 efek isolat Q3G maupun Q4G belum optimal, serta pada menit ke-45 efek isolat Q3G maupun Q4G memiliki potensi yang optimal. Pada menit ke60 efek isolat Q3G dan Q4G kembali mengalami penurunan, hal ini kemungkinan diakibatkan oleh kelelahan usus (exhausted) akibat proses penelitian, terjadi kebocoran kapiler usus yang dapat meningkatkan kadar gula yang dilakukan pemeriksaan dengan spektrofotometer.

Dari literatur diketahui bahwa ekstrak daun mimba yang memberikan efek penghambatan ambilan glukosa dalam jejunum tikus adalah 100 $\mathrm{mg} / \mathrm{kgBB} .{ }^{8}$ Hasil penelitian dengan menggunakan isolat bila dikonversikan ke dalam jumlah ekstrak daun mimba tampaknya berbeda dengan penelitian tersebut. Hal ini disebabkan dalam ekstrak daun mimba terdapat kandungan zat aktif lain selain Q3G dan Q4G yang memberikan efek penghambatan ambilan glukosa, seperti quercetin nonglikosida dan serat.

Simpulan, pemberian isolat Q3G dan juga Q4G yang diisolasi dari daun mimba dapat menghambat ambilan glukosa melalui membran usus halus tikus putih. Efek penghambatan ambilan glukosa melalui membran usus halus tikus putih oleh isolat Q3G dan Q4G yang diisolasi dari daun mimba berbeda pada menit ke-45. Efek penghambatan ambilan glukosa melalui membran usus halus tikus putih paling berbeda pada pemberian isolat Q3G $1 \mathrm{mg} / \mathrm{kg}$ BB tikus, Q4G $1 \mathrm{mg} / \mathrm{kg}$ BB tikus, dan Q4G $2 \mathrm{mg} /$ $\mathrm{kgBB}$ tikus.

\section{Ucapan Terima Kasih}

Peneliti menyampaikan ucapan terima kasih kepada Kemenkes RI atas Hibah RISBINIPTEKDOK tahun 2011 dan juga kepada berbagai pihak yang telah membantu sehingga penelitian ini dapat dilaksanakan.

\section{Daftar Pustaka}

1. Kementerian Kesehatan RI. Infodatin-Pusat
Data dan Informasi Kementerian Kesehatan RI. Situasi dan analisis diabetes. Jakarta: Kemenkes RI; 2014.

2. Perkumpulan Endokrinologi Indonesia (PERKENI). Jakarta: Konsensus Pengelolaan Diabetes Melitus di Indonesia; 2006.

3. Lehninger AL, Nelson DL, Cox MM. Principles of biochemistry. Edisi ke-4. New York: Worth Publisher; 2004.

4. Patil P, Patil S, Mane A, Verma S. Antidiabetic activity of alcoholic extract of Neem (Azadirachta Indica) root bark. Natl J Physiol Pharm Pharmacol. 2013;3(2):142-6.

5. Khosla P, Bhanwra S, Singh J, Seth S, Srivastava RK. A study of hypoglycaemic effects of Azadirachta indica (neem) in normal and alloxan diabetic rabbits. Indian J Physical Pharmacol. 2008;44(1):69-74.

6. Li JM, Wang $\mathrm{C}, \mathrm{Hu} \mathrm{QH}$, Kong LD. Fructose induced leptin dysfunction and improvement by quercetin and rutin in rats. Chinese J Nat Med. 2008;6(6):466-73.

7. Rainer C, Sandra L, Siegfried W. Quercetin glucosides inhibit glucose uptake into brush-border-membrane vesicles of porcine jejunum. Br J Nutr. 2005;91(6):849-55.

8. Yunivita V. The effect of neem leaf (Azadirachta indica A. Juss) ethanol extract on glucose uptake into white rat's intestinal mucosal membrane (Rattus rattus novergicus). Proceedings of the International Seminar \& Expo on Jamu; 2010 November 5-6; Bandung: Unpad; 2010

9. Islam M, Al-Amin M, Siddiqi MMA, Akter S, Haque MM, Sultana N, dkk. Isolation of quercetin-3-0-beta-D glucopyranoside from the leaves of Azadirachta Indica and antimicrobial and cytotoxic screening of the crude extracts. Dhaka Univ J Sci. 2012;60(1):11-4.

10. Akinola OB, Dosumu OO, Akinola OS, Zatta L, Dini L, Caxton-Martins EA. Azadirachta indica leaf extract ameliorates hyperglycemia and hepatic glycogenosis instreptozotocininduced diabetic wistar rats. Int J Phytomed. 2010;2(3):320-31.

11. Razavi SM, Zahri S, Zarrini G, Nazemiyeh $\mathrm{H}$, Mohammadi S. Biological activity of quercetin-3-0-glucoside, a known plant flavonoid. Bioorg Khim. 2009;35(3):414-6.

12. Tatke $P$, Desail $S$, Gabhe SY. Isolation of quercetin 3-0- $\beta$-D-glucoside. American J Phytomed Clin Ther. 2014;2(7):870-6. 